\title{
Comunicação
}

[Communication]

\section{Inquérito sorológico para toxoplasmose em equinos na região de Botucatu-SP}

\author{
[Serological survey of toxoplasmosis in horses from Botucatu region, SP] \\ L.G. Camossi, A.V. Silva, H. Langoni*
NUPEZO - Departamento de Higiene Veterinária e Saúde Pública
Faculdade de Medicina Veterinária e Zootecnia - UNESP
Distrito de Rubião Júnior, s/n
18618-000 - Botucatu, SP

A toxoplasmose é uma antropozoonose parasitária comum tanto no homem como em animais, causada pelo protozoário Toxoplasma gondii, parasita intracelular obrigatório de ampla distribuição mundial.

Os equinos estão entre as espécies domésticas mais resistentes à infecção pelo parasita e podem apresentar alguns sintomas caracterizados por hiperirritabilidade, incoordenação motora, distúrbios oculares e aborto (Turner e Savva, 1991). Não há evidência definitiva que $T$. gondii cause doença clínica em cavalos (Dubey et al., 1999), entretanto formas bradizoíticas do parasito foram isoladas de tecido muscular de cavalos saudáveis, indicando que o consumo de carne de cavalo inadequadamente preparada constitui via de transmissão para a infecção humana. Esse resultado foi reforçado pelo estudo de Dubey et al. (1999), em que, entre 1788 cavalos destinados ao abate nos Estados Unidos, $124(6,9 \%)$ foram considerados sorologicamente positivos. A carne de equinos pode constituir fonte de infecção para os animais de zoológicos, em especial para os felídeos, hospedeiros definitivos do agente. Estes, quando primoinfectados, podem eliminar oocistos no ambiente, pelas fezes (Dubey, 1985).

Dentre as provas sorológicas para a pesquisa de anticorpos anti-Toxoplasma gondii, duas se destacam, a técnica de aglutinação direta modificada (MAD) e a reação de imunofluorescência indireta (RIFI). Levando-se em consideração a importância da toxoplasmose no contexto de saúde animal e saúde pública, o grande número de espécies susceptíveis e o reduzido número de pesquisas que mostram a participação da espécie equina na epidemiologia da toxoplasmose, este trabalho teve os objetivos de estudar a infecção toxoplásmica em amostras de soro de equinos no município de Botucatu pela MAD e RIFI e comparar os resultados obtidos pelas duas provas.

Foram pesquisadas 253 amostras de soro de equinos, obtidas a partir do banco de soros, das amostras encaminhadas em 2007 para diagnóstico de anemia infecciosa equina, ao Serviço de Diagnóstico de Zoonoses da Faculdade de Medicina Veterinária e Zootecnia, UNESP, Campus Botucatu. As informações epidemiológicas foram coletadas a partir da análise da ficha de requisição para diagnóstico de anemia infecciosa equina, preenchida pelo veterinário responsável.

A RIFI para a detecção de anticorpos anti-T. gondii foi realizada conforme técnica padronizada e descrita por Camargo (1974), testando-se diluições de 1:16, 1:64, 1:256, 1:1024 e 1:4096 dos soros, em solução salina tamponada de fosfatos $\mathrm{pH} 7,2$, utilizando-se conjugado anti-IgG equina diluição 1:100 diluído em solução de azul de Evans a $4 \mathrm{mg} \%$. Como antígeno, utilizou-se exsudato peritonial de camundongos (Mus musculus), infectados com taquizoítos da cepa RH de $T$. gondii. Em todas as

Recebido em 6 de novembro de 2009

Aceito em 31 de março de 2010

*Autor para correspondência

E-mail: hlangoni@fmvz.br 
reações, foram incluídas amostras-padrão de soro, positivas e negativas, previamente conhecidas. Foram consideradas positivas as diluições dos soros iguais ou maiores a 1:16. (Dubey et al., 1999). Para execução da MAD, os soros foram diluídos como para RIFI e processados segundo o recomendado por Silva et al. (2007).

Para verificar a associação entre os resultados obtidos pelas duas técnicas empregadas, o teste de McNemar foi utilizado para avaliar a igualdade entre as proporções de positividade geradas pelas técnicas individualmente. Para calcular a probabilidade de associação das características em análise, utilizou-se o teste exato de Fischer. As variáveis idade, raça e sexo tiveram sua frequência absoluta analisadas segundo o resultado sorológico da RIFI.

Das 253 amostras testadas, considerando-se como ponto de corte o título 16, 32 delas $(12,6 \%)$ foram positivas pela MAD e $15(5,9 \%)$, pela RIFI. Com relação aos títulos obtidos, o maior foi 256 (uma amostra) pela MAD, e os mais frequentes 16 (19 amostras) e 64 (12 amostras). Pela RIFI, o título mais frequente foi 16 (14 amostras) e o maior título foi 64 (uma amostra). Houve diferença significante em relação à técnica empregada, quando se estipulou o título 16 como ponto de corte, com $\chi^{2}=359,97$ $(\mathrm{P}<0,0001)$, indicando haver diferença significativa na proporção de positivos e negativos indicada pelos dois testes, para $\alpha=0,05$ (Tab. 1).

Avaliaram-se, ainda, os resultados obtidos na RIFI com relação à idade. Os animais foram distribuídos em três faixas etárias - até cinco anos (cinco animais positivos), de seis a 15 anos (sete animais positivos), e de 16 a 25 anos (três animais positivos) e o $\chi^{2}=7,67 \quad(\mathrm{P}=0,1045)$ indicou não haver diferença significativa na proporção de positivos e negativos segundo a faixa etária, para $\alpha=0,05$.

Tabela 1. Concordância entre os resultados [frequência absoluta e frequência relativa (\%); intervalo de confiança a 95\%] da reação de imunofluorescência indireta (RIFI) e da técnica de aglutinação direta (MAD) na detecção de anticorpos anti-Toxoplasma gondii em soros de equinos, segundo o título de anticorpos

\begin{tabular}{c|cccc}
\hline \multicolumn{5}{c}{ Título/ RIFI } \\
\hline Título/ MAD & $<16$ & 16 & 64 & TOTAL \\
\hline \multirow{2}{*}{$<16$} & $221(87,35)$ & $0(0,00)$ & $0(0,00)$ & $221(87,35)$ \\
& $(82,68-90,88)$ & $(0,01-1,44)$ & $(0,01-1,44)$ & $(82,68-90,88)$ \\
\multirow{2}{*}{16} & $11(4,35)$ & $8(3,16)$ & $0(0,00)$ & $19(7,51)$ \\
& $(2,46-7,61)$ & $(1,63-6,11)$ & $(0,01-1,44)$ & $(4,88-11,44)$ \\
\multirow{2}{*}{64} & $6(2,37)$ & $6(2,37)$ & $0(0,00)$ & $12(4,7)$ \\
& $(1,11-5,07)$ & $(1,11-5,07)$ & $(0,01-1,44)$ & $(2,75-8,11)$ \\
\multirow{2}{*}{256} & $0(0,00)$ & $0(0,00)$ & $1(0,39)$ & $1(0,40)$ \\
& $(0,01-1,44)$ & $(0,01-1,44)$ & $(0,09-2,17)$ & $(0,09-2,17)$ \\
\multirow{2}{*}{ Total } & $238(94,1)$ & $14(5,5)$ & $1(0,4)$ & 253 \\
& $(90,44-96,36)$ & $(3,34-9,07)$ & $(0,09-2,17)$ & \\
\hline
\end{tabular}


Quanto à raça, segundo os resultados obtidos na RIFI, oito animais positivos eram sem raça definida e sete animais de raça definida (cinco Árabes, um Crioulo e um Quarto de Milha). A detecção de anticorpos anti-Toxoplasma gondii pelo teste exato de Fischer, com $\mathrm{P}=0,5060$, indicou não haver diferença significativa na proporção de positivos e negativos segundo a raça, para $\alpha=0,05$.

Quanto ao sexo dos animais, dos 253 animais analisados, 169 eram fêmeas, destas, 11 foram sorologicamente positivas para toxoplasmose na RIFI, e 84 eram machos, sendo quatro positivos na RIFI. O teste exato de Fischer, com $\mathrm{P}=0,4040$, indicou não haver diferença significativa na proporção de positivos e negativos, para $\alpha=0,05$.

Diversas provas sorológicas têm sido utilizadas na avaliação da infecção toxoplásmica, entretanto, na espécie equina, o teste diagnóstico de preferência ainda permanece desconhecido. Esse fato pode ser possivelmente justificado pelo menor número de estudos em equinos quando se compara com as demais espécies domésticas.

Ghazy et al. (2007) avaliaram a eficiência diagnóstica do ELISA indireto em comparação com RIFI e MAD no diagnóstico da toxoplasmose em 420 amostras de soro equino. Os resultados revelaram que o ELISA indireto com antígeno purificado fração LAb apresentou melhor sensibilidade $(51,7 \%)$, seguida pela MAD $(48,1 \%)$ e RIFI (40,5\%). Comparando apenas a MAD com a RIFI, 170 amostras $(40,5 \%)$ apresentaram anticorpos anti-T.gondii na diluição 1:64 pela reação de imunofluorescência indireta, contra 202 amostras $(48,1 \%)$ pelo método de aglutinação modificado, apontando diferenças entre os métodos utilizados.

Langoni et al. (2007) examinaram 1984 amostras de soro e encontraram 138 (7\%) positivas pela MAD, considerando-se como título positivo 64 . De 138 amostras positivas na MAD, 14 foram negativas à RIFI, mas a análise estatística indicou concordância entre os testes utilizados. Outro trabalho, realizado pelo mesmo grupo (Mendonça et al., 2001), estipulou como ponto de corte o título 64, e não verificou diferenças nos resultados entre as duas técnicas, porém, se fosse adotado o título 16, haveria diferença nos resultados obtidos para as duas técnicas, com
7,6\% de positividade para o MAD contra $4,4 \%$ para a RIFI. Segundo os autores, muitos soros mostraram-se positivos para uma prova e não para a outra. As diferenças no ponto de corte empregado nos métodos diagnósticos tornam a comparação entre os resultados de vários estudos complexa, e estes devem ser analisados com atenção.

Os resultados desta pesquisa estão de acordo com o verificado em vários trabalhos, em diferentes espécies. Normalmente a MAD resulta em maior número de resultados positivos e títulos ligeiramente maiores quando comparados com a RIFI, e, como aponta Dubey (1985), esse fato deve estar relacionado com diferentes subtipos de $\operatorname{IgG}$ detectados em cada teste sorológico, ou essas diferenças para baixas diluições do soro podem ser atribuídas a reações inespecíficas.

Neste estudo, a prevalência de $12,6 \%$ obtida na MAD apresenta valor semelhante ao obtido por Garcia et al. (1999) em amostras de equinos procedentes do estado do Paraná, com 12,1\% de prevalência, nesse caso pela RIFI.

A prevalência de 5,9\% encontrada pela RIFI assemelha-se à verificada por Langoni et al. (2007) em 1984 amostras de equinos procedentes de diversas regiões do Estado de São Paulo, submetidas à MAD, com $7 \%$ de positividade, similar à prevalência de 6,9\% encontrada por Dubey et al. (1999), na América do Norte, ao trabalharem com 1788 soros de equinos destinados ao abate, porém testados pela MAD.

Os resultados obtidos pelas duas técnicas são notadamente mais altos que o verificado por Mendonça et al. (2001), que, ao testarem 343 amostras de equídeos procedentes do Estado da Bahia, verificaram $5(1,5 \%)$ positivas tanto pela RIFI quanto pela MAD. Silva (2005) também encontrou baixa prevalência ao realizar um estudo em 15 fazendas do Pantanal do Estado do Mato Grosso do Sul, pela prova de hemaglutinação indireta. De 150 soros, somente $2(1,3 \%)$ foram positivos, com títulos acima de 64. Ressalta o autor que os dois cavalos permaneciam próximos às casas dos proprietários, que possuíam gatos para o controle de roedores, assim, pode-se admitir que essas espécies foram as possíveis fontes de infecção. 
Os resultados obtidos são significativamente mais baixos que os obtidos por Ghazy et al. (2007), que verificaram prevalências mais altas ao examinarem 420 amostras de soros de equinos, no Egito. Os autores encontraram pelas técnicas de RIFI, MAD e ELISA (LAb) 40,5\%, $48,1 \%$ e $51,7 \%$ de prevalência, respectivamente.

As diferenças de resultados entre os vários pesquisadores devem ser avaliadas quanto ao número de amostras pesquisadas e à metodologia empregada, pois essas variáveis podem interferir no resultado quanto ao título de anticorpo. Outro aspecto a ser levantado é a interpretação realizada pelo técnico, além de características dos reagentes, antígenos e conjugados que são utilizados pelos diferentes laboratórios. Independente desses fatores verifica-se que há diferença de resultados entre os mesmos pesquisadores, ao trabalharem com amostras de animais provenientes de diferentes locais, o que confirma a importância do ambiente na manutenção do agente e consequente transmissão da toxoplasmose tanto para os animais quanto para o homem.

As diferenças indicaram que a positividade encontrada em relação ao sexo, idade e raça não foram significativas, o que confirma os resultados verificados por Garcia et al. (1999) e Mendonça et al. (2001).

Sugere-se a realização de novos estudos para padronização de testes diagnósticos, bem como para o estabelecimento de título sorológico significativo de toxoplasmose para esta espécie. As técnicas de RIFI e MAD apresentam alta sensibilidade e especificidade, entretanto há aspectos favoráveis relacionados com a MAT, como simplicidade da técnica e custo, e pelo fato de não haver necessidade de equipamentos sofisticados.

Palavras-chave: equino, Toxoplasma gondii, sorologia

\begin{abstract}
The frequency of anti-T.gondii IgG antibodies was evaluated and compared in 253 sera samples of equines by modified agglutination test (MAT) and indirect immunofluorescent antibody test (IFAT). Fifteen samples (5.9\%) were positive by IFAT and 32 (12.6\%) by MAT. Significant difference between the two methods was found when a cutoff titer of 16 was established. There was no correlation with breed, gender, and age of horses examined.
\end{abstract}

Keywords: equine, Toxoplasma gondii, serologic

\section{REFERÊNCIAS BIBLIOGRÁFICAS}

CAMARGO, M.E. Introdução às técnicas de imunofluorescência. Rev. Bras. Patol. Clin., v.10, p.143-169, 1974.

DUBEY, J.P. Persistence of encysted Toxoplasma gondii in tissues of equids fed oocysts. Am. J. Vet. Res., v.46, p.1753-1754, 1985.

DUBEY, J.P.; THULLIEZ, P.; ROMAND, S. et al. Serologic prevalence of Toxoplasma gondii in horses slaughtered for food in North America. Vet. Parasitol., v.86, p.235-238, 1999.
GARCIA, J.L.; NAVARRO, I.T.; OGAWA, L. et al. Soroprevalência do Toxoplasma gondii, em suínos, bovinos, ovinos e equinos e sua correlação com humanos, felinos e caninos, oriundos de propriedade rurais do norte do Paraná, Brasil. Cienc. Rural, v.29, p.91-97, 1999.

GHAZY, A.A.; SHAAPAN, R.M.; ABDELRAHMAN, E.H. Comparative serological diagnosis of toxoplasmosis in horses using locally isolated Toxoplasma gondii. Vet. Parasitol., v.145, p.31-36, 2007. 
LANGONI, $\quad$ H.; $\quad$ SILVA, $\quad$ A.V. BERGAMASCHI, S. et al. Utilization of modified agglutination test and indirect immunofluorescent antibody test for the detection of Toxoplasma gondii antibodies in naturally exposed horses. Braz. J. Vet. Res. Anim. Sci., v.44, p.27-32, 2007.

MENDONÇA, A.O.; CERQUEIRA, E.J.L.; ARAUJO, W.N. et al. Inquérito sorológico para toxoplasmose em equídeos procedentes de duas regiões do Estado da Bahia, Brasil. Semina: Cienc. Agr., v.22, p.115-118, 2001.

SILVA, R.A.M.S. Antibodies to Toxoplasma gondii in horses from Pantanal, Brazil. Vet. Zootec., v.12, p.20-24, 2005.
SILVA, R.C.; SILVA, A.V.; LANGONI, H. Serological differentiation between acute and chronic stages in experimental toxoplasma infection of normal and immunosupressed rats (Rattus norvegicus). In: INTERNATIONAL CONGRESS IN ANIMAL HYGIENE, 13., 2007, Tartu. Proceedings... Tartu, 2007. v.2, p.885-888.

TURNER, C.B.; SAVVA, D. Detection of Toxoplasma gondii in equine eyes. Vet. Rec., v.129, p.128, 1991. 